\title{
An Empirical Access of Academicians as Building Blocks for Youth to Lead Quality Life
}

\author{
Jaya Surjani, Rahul Hiremath, K. Rajagopal
}

\begin{abstract}
Quality of life, amongst many concepts of social science is an important one, which is frequently used and also a part of the global cultural and political vocabulary. The happiness and longevity of life in nations is explained through quality-of-life. In a developing nation like India where the traditional education system still survives and relationship between a mentor/teacher and student is sacred and regarded highest among socialization process; the responsibility of an Academician in shaping the personalities is immensely diverse. This study explores the various dimensions of academicians as builder of humanistic society in order to live happy and healthy life. The young minds need to be cultivated for future to contribute as an independent, self sufficient citizen whose priority is not just contributing to GDP but to GNH. The study conducts a survey of students and teachers to understand the role in cultivating young minds for future. This further explores the dimensions of Quality of life that constitute Material living conditions, Health, Productivity, Education, Leisure and Social interactions, Economic and Physical Safety, Natural and living environment, governance and basic rights,; all these dimensions help in building a better social infrastructure of the country in order to sustain in the global economy.
\end{abstract}

Keywords : Quality of life, Happiness, Social infrastructure, youth, Academicians

\section{INTRODUCTION}

The youth is the future. We need to understand what makes individual more happy in their lives. This as a question has many answers in different contexts, whether in relation to work life, personal life, social surroundings, country and the people, economic stratification and the list is endless. It is really difficult to come to some conclusion. Though we can try to bring out some inferences and hence move towards happiness and peace amongst precious human lives. The youth acts as a life force for the development of the country and must be exposed to life in totality. Educating them in a right way can definitely bring happiness and joy in their lives which in turn affect the total environment of the country. As we take the example of Bhutan, that bases wellness of the economy to be calculated on the basis of Gross National Happiness (GNH) and not on Gross Domestic Product (GDP). All the developing nations are also trying to move towards this model to bring harmony and peace amongst each life. The social infrastructure of all

Revised Manuscript Received on September 10, 2019.

Dr. Jaya Surjani, Assistant Professor, Dept. of Advertising and Public Relations, Makhanlal Chaturvedi National University of Journalism and Communication, Bhopal, Madhyapradesh, India.

(E-mail- jaya.surjani0@gmail.com)

Dr. Rahul Hiremath, Infrastructure Department, SCMHRD, SIU Pune, Maharashtra, India

(E-mail-rahul_hiremath@scmhrd.edu)

Dr.K.Rajagopal, Marketing Department, SCMHRD, SIU Pune, Maharashtra,India

(E-mail-k_rajagopal@scmhrd.edu) countries aims to secure their environment basing their lives on quality of life. To understand the term let's consider the concepts of many divergent thinkers who can justify the parameters or domains of this subject.

As discussed by Farquhar's (1994), three main categories of understanding are mentioned which are global, component and focused definitions. One of the global definition that is rather popular, defines the Quality of Life (QOL) as the expression, the degree of satisfaction or dissatisfaction felt by people in various aspects of their lives.(Abrams,1973). Or, to understand it in simpler form, quality of life is important requisite of the necessary conditions for happiness and satisfaction (McCall, 1975). The second category, the component definition elaborates and stresses the multidimensional nature of QOL and gives clarity to various dimensions. George and Bearon (1980) identified four dimensions, the health and functional status were termed to be 'objective' and socioeconomic status and two others life satisfaction and self esteem are 'subjective'. In contrast to this eight dimensions have been highlighted by Hughes (1990) that describe 'constituent elements', which are part of the conceptual model of quality of life that include socio-economic status, purposeful activity, personal autonomy, expressed satisfaction, quality of the environment, physical and mental well-being, social integration and cultural factors.

The third view, focused definition, centers on few dimensions that tend to reflect on the political or professional agendas of various disciplines. For example, quality of life often describes on health and functional status measures within health services research (Bowling, 1996) and on utility assessment, in relation to health economics (Torrance, 1986). Wellbeing has been regarded as one of the important factors of QOL, Pollard and Lee described the term well-being as "a complex, multi-faceted construct that has continued to elude researchers attempts to define and measure it."

Gross National Happiness is to improve happiness and create institutions, which can promote such endeavor. The new GNH Index provides a summary in quantitative data of the wellbeing of individuals. In order to understand the multidimensional concept of Gross National Happiness ... four areas are defined. These are termed as the four pillars of GNH, which are:

1. Development based on sustainability \& equitable socio-economic status;

2. Conservation of Environment;

Published By 


\section{Protection and advancement of culture; and}

4. Good governance.

Hereafter, GNH was explained through nine dimensions that specify the four pillars. The dimensions are: health, psychological wellbeing, community vitality, time use, education, cultural diversity and resilience, living standard, good governance, and ecological diversity and flexibility. The motivation for including each dimension is detailed below. They are related to Public Policy, novelty and innovation. Three traditional dimensions of public policy as domains are: Living standard, health, and education are part of Public policy that becomes the bases for other parameters. Ecological diversity and good governance are comparatively more thoughtful concepts of global discussions that have been of prime importance in today's era. The dominant dimensions personal well-being, time use, community exuberance and multiculturalism are distinct and innovative.

This paper tries to investigate the understanding of quality of life for youth and their awareness about gross national happiness and the index that would base the future generations in order to bring both economic and social stability in the country. Also dwells into the role of academicians for these young to be professionals to cultivate them for this new world based on quality of life that leads to happiness and peace instead of GDP.

\section{RESEARCH METHODOLOGY}

This research paper is attempt to explore how the motives of quality living are gaining importance in people's lives for sustainable growth of the country. Also it tries to highlight the role of academicians in fostering the young minds to lead happy life considering the parameters of quality of life.

\section{REVIEW OF LITERATURE:}

This subject is taken up for studies in different contexts and no detailed research relates to academicians and their motivation in building the lives of the students leading a quality life and improve their well being and happiness. Some studies talk about quality of work life of academicians that does not relate at all.

Some studies talking about the cultural social impact research has been discussing culture in regards to Quality of life and well-being. The researches lack empirical evidence, and theoretical basis to support the establishment of the impact of cultural contribution. In the process, Referring the Urban Institute's literature review of the impact of cultural participation, Jackson mentions how community development and social capital research have been largely neglecting the unique and considerable role of arts and cultural activity.

Some research studies discussed by Coffman tried to evaluate the effects of music participation on dimensions of well-being. These found that music has both significant and effective results, in terms of social bonding and self actualization and empowerment, in regards to music making also. These findings also relate to Ruud's summary of his empirical work on music and identity explains the contribution of music to quality of life and relation to happiness or subjective well-being. These were explained as

four strands as in music: well-being in emotional context, an enhanced ability to express feelings and experience; an increased sense of "agency", sense of purpose, empowerment, and "social competence"; strengthened feelings of "belonging" and community identity; and the development of a meaningful sense and life coherence.

A study for living standard improvement on GNH philosophy conducted by Shuichi Hirayama, Japan concluded that the philosophy stressed on the economic aspect of life in measuring of standard of living and does not give weightage to human satisfaction of life. This leaves a greater scope of research in wider perspective. The examples of comparing GDP to GNH are still more challenging to understand and conduct research. The micro and macro levels understanding has to be strengthened by concrete research in various areas.

A book, The Quality of Life; edited by Professor Martha Nussbaum, and Amartya Sen is an engaging collection of different understandings of the concept. The book discusses about the idea of the concept that it focuses on economic and social evaluation; social legislation; also to public policy and community programs. However, for measuring QOL, the familiar indicators of economic prosperity such as per capita income are the crude measures for it. It stresses the requirement of systematic exploration of the content, reach, and relevance, also allows more clarity to give it due importance in human lives. In this edition of detailed articles, some prominent philosophers \& economists have taken it as a challenge and provided wide-ranging investigations.

Studying the review, some research questions related to my topic that would help this study to draw inferences.

Research questions:

- Do the academicians understand the quality of life parameters?

- What is the contribution of Academicians in promoting quality of life understanding amongst University students?

-What are the means of discussing these parameters?

- Do students regard QOL important for their happiness and good life?

- Do they want their education be based on the parameters of QOL?

- Do they regard QOL and GNH important for economic, social stability and sustainable development?

\section{Research Design:}

Quantitative research design is applied to understand the significance of Quality of life from the perspective of education by the teachers and the motives in student's life, within this the importance of various parameters is studied.

\section{Tools and Techniques:}

To fill the research objectives the research paper uses questionnaire to collect responses which is prepared for both Academicians and graduate/post-graduate students. The data is statistically analyzed for inferences. 


\section{Sampling:}

Purposive sampling techniques has been used for primary data collection. The University teachers including Assistant Professors, Professors have been considered as sample, 50 academicians were asked questions related to their thoughts and contribution, these were selected randomly from various institutions of Bhopal and Indore working with different specializations; also students of various professional courses have responded for this paper. The sample size of 100 students is considered for data analysis and conclusions are drawn.

\section{DATA ANALYSIS \& RESULTS}

The academicians were been surveyed for the study to draw inferences about the teacher student relationship and their sharing about quality of life, their choices and advocacies

-When asked about their consideration of quality of life as important to the income 97 percent regarded it as being equally important.

- To understand the link between income and quality of life academicians were

asked about income contribution to improve the quality of life; almost 80 percent

regarded income to be most important factor. But 12 percent says it contributes partially and around 6 percent were not sure.

- Around 85 percent are aware of GNH (Gross National Happiness)

-When asked about GNH index contribution to lead QOL; Approx. 62 percent could confirm that yes it does help to lead a fulfilling quality life. Around 30 percent were unsure about its contribution, they related only GDP to QOL.

- When asked about the parameters of QOL i.e. Material living, Productivity,

Health, Education, Leisure and Social interaction, Economic and basic rights, Nature and Environment; around 10 percent understood all of them, other respondents were unaware of either material living(15 percent), 12 percent didn't relate productivity to QOL. 16 percent didn't include nature and environment as important QOL parameter.

- Only 68 percent in all considered these dimensions to lead happy life. 24 percent said the happiness is subjective in nature so it depends on many other dimensions of life but when talking about national happiness, these are worthwhile.

- When asked are your students able to give these dimensions due importance in

their own lives around 60 percent partially regarded them as important.

-To know about their interaction about these parameters with their students, 32 percent have this orientation while discussing about good life, only 3 percent have never discussed about it as they never got chance to do so, working on the technical side.

- 68 percent are totally favoring QOL discussion with students as they feel

responsible in influencing them for right kind of living.
-45 percent say motivational experts should be invited to conduct interactive sessions to make them understand the value of QOL dimensions to lead a happy and peaceful life . 35 percent say their informal interaction and guidance can lead them to career that gives the QOL. Others also insist QOL topics to be included in curriculum for sustainable growth of human lives.

Now, talking about responses of students:

The data matches the academicians feedback and this clearly signifies that teacher plays an important role in helping students to choose career options as per their interest and joyful living and not just focus on earning money to live life. Happiness and peace centric life can be more satisfactory.

Students have their concepts of life and the importance of some parameters in life was investigated. (Table I) The respondents ranked Family, Health, Wealth, Peace/Happiness, Social Status, entertainment, environment. Mean and std. deviation is shown here, the social status has higher value than 2, that shows insignificance; the other parameters have low to high significance (values between 0 2 are significant). The family is most important (SD:0.480 $\leq$ 2) for their lives which proves that Indian youth would always regard families as their bases for growth.

\section{Table I}

\begin{tabular}{|c|c|c|c|c|c|c|c|}
\hline & $\begin{array}{l}\text { Fam } \\
\text { ily }\end{array}$ & $\begin{array}{l}\text { Hea } \\
\text { lth }\end{array}$ & $\begin{array}{l}\text { Wea } \\
\text { lth }\end{array}$ & $\begin{array}{l}\text { peace/ } \\
\text { Happi } \\
\text { ness }\end{array}$ & $\begin{array}{l}\text { Soci } \\
\text { al } \\
\text { stat } \\
\text { us }\end{array}$ & $\begin{array}{l}\text { Enter } \\
\text { tainm } \\
\text { ent }\end{array}$ & $\begin{array}{l}\text { Envi } \\
\text { ron } \\
\text { men } \\
\text { t }\end{array}$ \\
\hline Mean & 1.65 & 1.99 & 2.49 & 3.51 & 4.50 & 5.48 & 5.78 \\
\hline $\begin{array}{l}\text { Std. } \\
\text { Deviati } \\
\text { on }\end{array}$ & .480 & .886 & $\begin{array}{l}1.01 \\
3\end{array}$ & 1.631 & $\begin{array}{l}2.00 \\
4\end{array}$ & 1.225 & .511 \\
\hline
\end{tabular}

When asked for the job requisities, i.e what all things you look while taking up jobs, some parameters were suggested to be ranked in order of importance, they want their jobs that provide them several things like Economic status, Wealth, Social status, Healthy environment, Opportunity for growth , Job of your interest. Standard deviation values below; help to conclude the significant parameters. Social status, health benefits, healthy environment has been seen as major criteria with SD $(1.20,1.27,1.077 \leq 2)$ (Table II)

Table II

\begin{tabular}{|c|c|c|c|c|c|c|c|}
\hline & $\begin{array}{l}\text { We } \\
\text { alt } \\
\text { h }\end{array}$ & $\begin{array}{l}\text { econ } \\
\text { omic } \\
\text { Stat } \\
\text { us }\end{array}$ & $\begin{array}{l}\text { Soc } \\
\text { ial } \\
\text { Sta } \\
\text { tus }\end{array}$ & $\begin{array}{l}\text { Heal } \\
\text { th } \\
\text { beni } \\
\text { fits }\end{array}$ & $\begin{array}{l}\text { He } \\
\text { alt } \\
\text { hy / } \\
\text { goo } \\
\text { d } \\
\text { env } \\
\text { iro } \\
\text { nm } \\
\text { ent }\end{array}$ & $\begin{array}{l}\text { op } \\
\text { por } \\
\text { tun } \\
\text { ity } \\
\text { to } \\
\text { gro } \\
\text { wt } \\
\text { h }\end{array}$ & $\begin{array}{l}\text { Job of } \\
\text { your } \\
\text { interes } \\
t\end{array}$ \\
\hline $\begin{array}{l}\text { Me } \\
\text { an }\end{array}$ & $\begin{array}{l}4.1 \\
7\end{array}$ & 3.21 & $\begin{array}{l}3.3 \\
1\end{array}$ & 2.44 & $\begin{array}{l}3.6 \\
3\end{array}$ & $\begin{array}{l}4.9 \\
1\end{array}$ & 5.69 \\
\hline $\begin{array}{l}\text { Std. } \\
\text { Dev } \\
\text { iati } \\
\text { on }\end{array}$ & $\begin{array}{l}2.1 \\
68\end{array}$ & $\begin{array}{l}1.72 \\
2\end{array}$ & $\begin{array}{l}1.2 \\
01\end{array}$ & $\begin{array}{l}1.27 \\
5\end{array}$ & $\begin{array}{l}1.0 \\
77\end{array}$ & $\begin{array}{l}2.1 \\
18\end{array}$ & 1.772 \\
\hline
\end{tabular}


-According to 55 percent students, they agree that their teachers guide them towards happiness driven employment. Only 12 percent say that they have never been guided.

- 51 percent approximately also agree that their teachers have been talking about quality of life and its parameters for Indian economy, also from these 51percent ,78 percent say that they are totally influenced by their teachers to lead a good life.

-Around 36 percent of respondents also chose their career under teacher influence, that shows a good percent still follow the traditional method of learning where in gurukul system students worked strictly under teachers pattern.

- Surprisingly 52 percent advocate the old learning system to be more effective wherein healthy learning environment existed and hence the happiness and peace factors were more important as compared to only creation of wealth. In the above findings also family is been regarded as most important for healthy living.

- Also, 68 percent students agreed that teachers help us to focus on Quality life rather than just earning money.

-Students are aware of GNH being important for countries wellbeing, 66 percent are in favor of using GNH as criteria for development as done in Bhutan and some other countries.

- When asked about the parameters of Quality of life, quality education and others were equally regarded important.

- Also, 72 percent want today's university education to include this GNH index in the curriculum like GDP through some seminars, discussions, expert sessions.

\section{CONCLUSIONS \& SUGGESTIONS}

- The academicians understand the quality of life parameters to a great extent.

-The contribution of Academicians in promoting quality of life understanding amongst University students is improving $\mathrm{t}$ a good pace.

-The means of discussing these parameters are Expert Sessions, informal interactions, Career Counselling

-Yes, students regard QOL important for their happiness and good life and are looking towards sustainable future based of GNH.

-Yes, they want their education be based on the parameters of QOL, they are willing to be guided by their teachers for fulfilling careers.

-Yes, a good percent regard QOL and GNH important for economic, social stability and sustainable development

The future of the country can be based on peace and happiness if our education system, the academicians contribute to this important aspect of our countries prosperity and growth.

Further research is proposed to get a deeper understanding of correlation amongst many other parameters. As this research could limitedly be studied in many aspects, there is much more scope of study.

\section{REFERENCES:}

1. Argyle M. (2001), The Psychology of happiness. 2nd ed. New York: Routledge

2. Bowling, A ,McFarquahar, et al. Quality of Life and social well-being in older age in older age, NDA programme, report

3. Coffman \& Adamek (1999) „The Contributions of Wind Band Participation to

4. Quality of life of Senior Adults"e, Music therapy Perspectives 17(1), 27-31January,1999

5. Cummins, R. A. (2001), The Subjective Well-Being of People Caring for a Severely Disabled Family Member at Home: A Review, Journal of Intellectual and Development Disability, 26(1): 83-100.

6. Cummins, R. A (2000), Objective and subjective quality of life: an interactive model, Social Indicators Research, 52(1): 55-72.

7. Diener, Ed and Suh, Eunkook (1997) 'Measuring Quality of Life: Economic, Social, and Subjective Indicators', Social Indicators Research, Vol. 40, No. 1-2, p.191.

8. Farquhar, M. (1994). Quality of life in older people. Advances in Medical Sociology, 5, 139-158.

9. Farquhar, M. (1995). Elderly people ees definitions of quality of life. Social Science and Medicine, 41(10), 1439-1446Kinga.S (1999), "Gross National HappinessDiscussion Papers", The center for Bhutan Studies, Bhutan.

10. Lucas, R.E., Diener, E. \& Suh, E. (1996). Discriminant validity of well-being measures. Journal of Personality and Social Psychology, 71 (3), 616-628.

11. Veenhoven, R. (1999a) Quality-of-life in Individualistic Society: A Comparison of 43 Nations in the Early

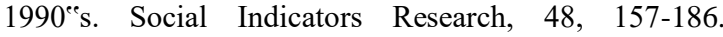
Veenhoven, R. (2000c) The Four Qualities of Life: Ordering Concepts and Measures of the Good Life. Journal of Happiness Studies, 1-1,1-39.

12. Torrance, G. Measurement of health state utilities for economic appraisal: A review, Journal Of Health Economics, 1986, vol. 5, issue 1, 1-30

\section{AUTHORS PROFILE}

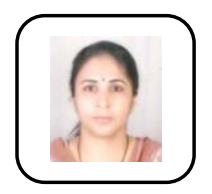

\section{Dr. Jaya Surjan}

Designation: Assistant Professor, Public Relations and Advertising Department, Makhanlal Chaturvedi National University of Journalism and Communication, Bhopal.

Creditentials:

Awarded Ph.D in Advertising in 2010. A Postgraduate in Advertising and Public Relations Management from IMS, DAVV, Indore.

Involved in teaching UG and PG students of Mass Communication and Advertising since last 18 years. Provided guidance to Research Scholars of M.Phil and Ph.D coursework. Specialized in teaching subjects like Human Communication, Management, Marketing, Consumer Behavior, Media Planning, Corporate Communication, Public Relations and so on.

Writing for various leading Media Journals, participated and presented papers in several International and National Conferences and Seminars. Member of professional bodies like AIMA and PRSI

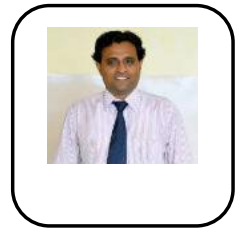

Dr.Rahul Hiremath Assistant Professor-IDM Department,SCMHRD. SIU Pune

Subject Specialist: Sustainability, Energy andclimate change. Participated in Various International conferences and has presented research papers in reputed International Conferences in India and abroad.

Award and Honors received:-

Subir Chowdhury Fellow, London School of Economics and Political science, London. 
Selected to represent India for the Energy Program as a youngest Researcher, at the Asian Institute of Technology (AIT), Bangkok, Thailand. Nominated for the Young Professional Programme of the World Bank

Dr. Kannan Rajagopal holds 15 years' experience of Teaching Management course both as Adjunct and Full Time Faculty in reputed Educational Institutions across the country. He has pursued his PhD in Marketing and $\mathrm{PhD}$ in HR and is associated currently with SCMHRD,

SIU Pune as a full time faculty of Marketing and General Management. He has presented research papers in reputed International Conferences in India and abroad. He has 2 decades of work experience in Automotive Marketing. 